\section{Operators to cooperate}

\section{Boston}

NExT month in Moscow, the World Association of Nuclear Operators (WANO) will begin formal operations, ushering in what supporters hope will be an era of increased international cooperation among the world's nuclear power industries.

WANO was conceived initially in response to the accident at the Chernobyl reactor in 1987. Participating power plants will share information about the safe operation of their plants and the details of any "off-normal" events through a worldwide computer network. The association has already opened regional centres in Paris, Toyko and Atlanta (Georgia), and a coordinating office in London. A fourth is due to open in Moscow later this month. In a remarkable show of solidarity, the organization will include the particpation of every nuclear utility in all of the 31 countries that use the technology to generate electricity.

Through its regional centres, the group will collect data about all mishaps and untoward events at nuclear power plants, and will organize workshops and technical exchange visits between nuclear operators from different nations.

While other international organizations exist to promote the safe use of atomic energy, WANO is unique in its exclusive orientation to industry, and its goal of uniting nuclear-plant operators worldwide. WANO is modelled on an existing organization in the United States called the Institute of Nuclear Power Operations (INPO) which was also formed in response to a nuclear mishap-the partial meltdown at Three Mile Island in 1979 (see Nature 338,190;1989).

Greater information exchange among nuclear operators might have prevented the operator error that led to the accident at Three Mile Island, according to many INPO staff. Addressing participants at an INPO conference in Atlanta last fall, Lord Marshall, chairman of the WANO Steering Committee, stated that the accident at the Chernobyl reactor "never would have happened" if WANO had been in place and "working effectively". "Peer group pressure" would have forced changes in the "unacceptable" degree of reliance on the operator in the safety design of the Chernobyl plant, said Thomas Eckered, acting director of the London WANO coordinating centre.

Marshall stressed the importance of the choice of Moscow as the location of the inaugural meeting of the group. That, he said, shows the acceptance by the world nuclear industry of Soviet commitment "to glasnost and perestroika in their nuclear business."

Seth Shulman

\title{
Proliferation of nuclear subs
}

\section{Boston \& São Paulo}

FEARS that the acquisition of nuclearpowered submarines by Brazil, India and Canada will blur the line laid out in the Nuclear Non-Proliferation Treaty and foster the spread of nuclear weapons to developing nations are largely unfounded, according to the majority view at a meeting held last week at the Massachusetts Institute of Technology (MIT). But military and technical experts from several nations, including those planning to acquire nuclear-powered submarines, agreed that there are real fears that deployment of nuclear submarines could trigger regional arms races in South Asia and South America.

Brazil, India and Canada are all planning to build or buy nuclear-powered submarines. India last year leased a nuclear submarine from the Soviet Union and is rumoured to be negotiating for three more, even as it continues work on its own development programme. K.K. Nayyar, retired vice-admiral of the Indian Navy, defended his nation's nuclear-submarine programme not only by emphasizing its deterrent capability but also by acknowledging India's desire for a stepped-up military presence in the Indian Ocean. "India represents 17 per cent of the population of the planet", Nayyar stated, "we want to be there to be reckoned with".

Brazil too has regional power plans. A statement from Mario Cesar Flores, an admiral in the Brazilian Navy, said that
Brazil's ambition to have a "strong presence" in the South Atlantic leads it "in a firm, prudent and deliberate fashion, to the nuclear-powered submarine". Brazil was apparently impressed by the performance of British nuclear submarines during the Falklands war.

Three conventional submarines are now being built in Brazil with West German help while indigenous efforts are made to develop small reactors and enrich nuclear fuel at the Centro Experimental Aramar at Iperó near Sāo Paolo. According to Adrian English, a US expert on Latin America's military balance, as soon as Brazil deploys a nuclear-powered submarine, "two to four nations in the region will be sure to follow suit", including Argentina. Chile and Cuba.

The role of nuclear-powered submarines in regional conflicts seems a bigger problem than their impact on nucleararms programmes. Several participants at the meeting pointed out that the countries currently investigating the development of nuclear submarines already have nuclear-power programmes and "plenty" of plutonium for weapons at their disposal. Brazil's Admiral Othon Pihheiro, known locally as the "Brazilian Rickover", claimed success for the nuclear enrichment programme last week, saying that the first batch of enriched uranium reactor fuel will be delivered at the end of the year.

Seth Shulman \& Ricardo Bonalume Neto

\section{ENVIRONMENTAL PROTECTION}

\section{Trouble at the mill in Australia}

\section{Sydney}

Plans for a \$1,000-million chemical pulp mill in Tasmania have been scrapped after the Australian government decided to impose strict environmental controls as a condition of approval for foreign investment in the project. The mill, at Wesley Vale, was to have been a joint venture between the Australian company North Broken Hill Peko and its Canadian partner Noranda.

Such environmental guidelines are usually set by the state government. It is believed that the Tasmanian government agreed to loosen its guidelines because of the employment opportunities offered by the project. But in this case, because of the level of foreign investment, the project had to be approved by the federal government's foreign review board.

At issue is the production of dioxins, which occurs when mills bleach paper with chlorine. In humans, dioxin exposure causes the skin disorder chloracne and has been linked to other illnesses. According to government sources, the companies involved in Wesley Vale were not prepared to spend enough money to replace dioxins in the bleaching process, or to change the mill's effluent pipeline into Bass Strait.

The Minister for the Environment, Senator Graham Richardson, has come under strong pressure from the government to develop clear-cut environmental guidelines. While agreeing to do so, Richardson has stated that differing circumstances in individual cases may make them difficult to formulate.

Companies at present planning three other pulp mills in Victoria, New South Wales and West Australia, all similar in scale to Wesley Vale, are unlikely to proceed without comprehensive guidelines.

Prime Minister Bob Hawke told the Australian Broadcasting Corporation radio programme "PM" that he recognized that the loss of the mill would damage both investment in Australia and export earnings. "As long as I'm Prime Minister I won't have development at any price. Each day they would be dumping 13 tonnes of organochlorides into the ocean and I will not allow it."

Tania Ewing 